\title{
Barndommens egenverdi på spill?
}

\author{
Av Marte Eriksen
}

\begin{abstract}
MARTE ERIKSEN (f. 1975). Barnehagerådgiver ved IKO og masterstudent ved HiVe. Adr.: IKO, Pb. 2623, St. Hanshaugen, 0131 Oslo, Epost: marte.eriksen@iko.no
\end{abstract}

Barnehageloven $\$ 1$ tredje ledd sier at barnehagen skal anerkjenne barndommens egenverdi (Kunnskapsdepartementet, 2011). Stortingsmelding 24 «Framtidens barnehage» slår også fast at «Småbarnsalderen er ikke en livsfase som $i$ hovedsak handler om forberedelser til en voksenverden, men en fase der det enkelte barn skal vokse ut fra egne forutsetninger og oppleve å bli sett og respektert som seg selv.» (Kunnskapsdepartementet, 2013, s. 11).

Denne målsettingen er i tråd med tradisjonell barnehagepedagogisk tenkning, og det er lett å si seg enig. Den handler om hvilket syn vi har på barn, og om hvilken verdi vi gir her og nå øyeblikkene og de gode opplevelsene som oppstår i det spontane, og i relasjonene. Men det handler også om hvilket syn samfunnet har på barn. Om samfunnet verdsetter at barndommen er en livsfase med egen verdi, der ikke all innsats vurderes ut fra hvilken økonomisk og framtidig nytteverdi den kan ha. Barnehagelovens anerkjennelse av barndommens egenverdi stadfester at det er barnehagens oppgave og mandat å gi rom for spontanitet, lek og omsorg som gir mening for barnet her og nå.

Jeg oppfatter signaler både i det politiske ordskiftet, i offentlige plandokumenter, utredninger og meldinger, samt i møte med den kommunale styringen av området, om at dette er en verdi man beveger seg bort fra. Jan-Erik Johansson definerer dette som en ideologisk konflikt: «Har barndomen ett egenvärde, eller är den främst en trening för skolan og vuxenlivet?» (Johansson, 2010). En antagelse om synkende fokus på anerkjennelsen av barndommens egenverdi, er kjernen i det barnehagepolitiske temaet jeg vil ta opp her.

I 1999 var jeg ferdig utdannet førskolelærer og startet som pedagogisk leder. Jeg skrev årsplaner med lange avsnitt om pedagogiske idealer og hva som skulle styre personalgruppen i vårt arbeid. Utgangspunktet var rammeplanen fra 1995, som var minst like omfattende i sine beskrivelser. Etter et par år i feltet kom de første utspillene fra bydelen om målstyring. Vi ble instruert i hvordan vi skulle formulere målsettingene. De skulle defineres og konkretiseres i kjennetegn ved barna som gjorde det mulig å evaluere måloppnåelsen i etterkant. Dette er et beskjedent eksempel på endringer jeg opplever har seilt inn i barnehagefeltet. Endringer er ikke negativt i seg selv. Men det kan for meg se ut som at barnehagen i økende grad anses som en arena for iverksetting av tiltak for å oppfylle målsettinger utenfor barndomsfeltet og barnehageområdet.

«JEG BRUKER DET SPRÅKET JEG MÅ FOR Å BLI HØRT AV ØKONOMENE ...» ... sa daværende kunnskapsminister Kristin Halvorsen en uke før valget høsten 2013. Anledningen var et debattmøte med barnehage som tema - i lærernes hus. Statsråden besvarte spørsmål fra salen om hvorfor hun brukte markedstermer innenfor barnehageområdet. Vi 
kjenner til utsagn om at for hver krone investert i barnehage, får vi opptil flere igjen. Dette er utsagn som jeg tenker at finner gjenklang i Katrin Hjorts beskrivelse av velferd som en investering (Hjort, 2008). Hun argumenterer for at en slik tenkning bidrar tilå objektivere borgerne. Historikeren Tora Korsvold peker også på at barn i stadig større grad blir definert som humankapital, og dermed blir barndommen et rom for predefinert læring som samfunnet behøver for å være konkurransedyktig (Seland, 2010). Jeg tror Halvorsen egentlig ønsket å berolige forsamlingen om at hun hadde forstått hva barnehagefaget handlet om, og samtidig gjøre det klart at man må spille på lag med de som ikke forstår det barnehagefaglige anliggendet. Derfor måtte hun tilpasse språk og argumentasjon til en New Public Management (NPM)-tenkning. Dette er en måte å tenke om offentlig sektor på som blir stadig mer vanlig. Kanskje forsøker man å skille mellom det interne fagspråket og den faglige tenkningen som bærer i seg grunnleggende verdier barnehagen skal bygge på, og det språket man velger å bruke «ute» blant de som vi har erfart at ikke forstår hva vi holder på med. De som må argumentere for alle investeringer med mulig avkastning. Men denne tenkningen kan innebære at offentlig forvaltning blir underlagt styringsrasjonaler som bygger på markedslogikk (Kampmann, 2009). En slik logikk orienterer seg mot konkurranse, prestasjoner og produktivitet, begreper som kan oppleves som motstridende til ideen om barndommens egenverdi.

Den daværende statsrådens pragmatiske tilnærming beroliger meg ikke, siden jeg tror hun overser og bagatelliserer kraften og makten som knytter seg til språk. For nye måter å tenke om og forstå et fenomen på, endrer menneskers oppfatning av hva som er sant, rett og godt. Nye diskurser skaper mulighetsrom for endring av både holdninger og handlinger (se Monica Seland om governmentality). Et eksempel på dette kan være den forståelsen vi i dag har av barns selvstendige rett til å bli hørt i saker som angår dem, noe man tenkte ganske annerledes om for bare noen tiår siden. Kunnskap om barn og barndom har endret seg. Dette påvirker både den indirekte styringen av mentalitet, governmentality, og den mer formelle styringen av barndom gjennom lover og planer for barndomsfeltet. Noe som igjen har medført endringer $\mathrm{i}$ våre holdninger og handlinger. Den tidligere statsråden og andre sentrale meningsbærende aktørers bruk av markedstermer for å forsvare samfunnets økonomiske satsing på barnehage, kan bidra til at den rådende oppfatningen av barnehagens oppgave og mandat endres. Dersom den uttalte målsettingen med barnehage synes å knytte seg til fremtidig deltakelse i studier og arbeid, forebygging av problemer i skolen, likestilling, og mindre til barndommens her og nå, kan det bidra til en endring av den generelle tenkningen om barndommens egenverdi.

\section{DEN FREMMEDGJORTE PROFESJONSUTØVER}

I «Barndommens modernisering» belyser Thomas Gitz-Johansen ulike organiseringsprosesser på barndomsområdet (Gitz-Johansen, 2009). Han gjør rede for endrede betingelser for barndom og forklarer endringene med diskurser om modernitet, med utviklingen i offentlig styring av barnehagen som eksempel. Han bruker begrepene emansipatorisk modernitet og autoritær modernitet, og forklarer hvilke pedagogiske tankemodeller disse reflekterer. Emansipatorisk modernitet strekker seg tilbake til siste halvdel av 1900-tallet og springer ut fra et oppgjør med autoritære oppdragelsesformer (Gitz-Johansen, 2009, s. 73-77). Noen av de sentrale teoretikerne innen paradigmet er Jean-Jacques Rousseau med sine teorier om det frie barnet og utvikling av det iboende i mennesket, John Deweys tenkning som regnes 
som opphavet til den progressive pedagogikk, og Oskar Negts utvikling av begrep om erfaringspedagogikk. Nye pedagogiske prinsipp, med ansvar for egen læring, gruppesamarbeid og undervisningsdifferensiering, ble gjort gjeldende i denne perioden. Begrepet som ”Det kompetente barnet" ble introdusert av Jesper Juul. Den frie leken og barns mulighet for medbestemmelse er med å tegne bildet av en pedagogikk som la opp til selvforvaltning. FNs konvensjon om barns rettigheter fra 1989 bidro også til å gi den frigjøringspedagogiske tenkningen en juridisk forankring.

Gitz-Johansen viser så til en dreining bort fra denne reformpedagogikken, i retning av den autoritære modernitet som kanskje utgjør et nytt paradigme, stadig mer gjeldende fra 2000tallet. Denne modernitetens prosjekt bygger på en tenkning om å skape orden i det uordnede, og unngå flertydighet og kaos, ifølge Zygmunt Baumann som er en av de fremtredende modernitetstenkerne (Gitz-Johansen, 2009, s. 77-80). For barndomsområdet betyr dette innføring av byråkratiske rasjonaler, gjennom normering og standarder ut fra et behov for å definere hva som er normalt og unormalt, hva som er fremmed og hva som hører til. GitzJohansen beskriver dette som en systematisk måte å skape orden på. Styring blir i økende grad lineær og rasjonell, og baserer seg på kausalitetsprinsippet. Overordnede målsettinger evalueres gjennom kartlegging og målinger, som igjen får tilsynelatende logiske konsekvenser for fastsettelse av nye mål. Dette er en måte å styre på som kan bidra til forenklinger av i utgangspunktet komplekse forhold.

Gitz-Johansens artikkel er skrevet i en dansk barnehagekontekst. Ut fra beskrivelsene ser den danske barnehagen ut til å ha læreplaner med konkrete læringsmål og standardisering og kanonisering av det tematiske innholdet som barna skal bli kjent med i løpet av barnehagetiden, og en mer utstrakt evalueringskultur enn den norske barnehagens rammeplan legger opp til. Til tross for at jeg oppfatter moderniseringsprosessen i Danmark som mer framtredende enn i Norge, er likheten med norske forhold relativt stor, og gir overføringsverdi til norsk barnehagekontekst. Gitz-Johansen presenterer etter min mening noen ideologier og diskurser som kan bidra til å beskrive dreiningen i argumentasjon for satsing på barnehage som jeg fornemmer blir stadig mer allmenn.

Knud Jensen og Stephen A. Walker viser hvordan innføring av kapitalistiske prinsipper med markedstenkning på makronivå bidrar til et behov for normering og standarder. ${ }^{1}$ Målstyring blir et viktig verktøy for arbeidet. Det står sentralt både i planlegging og i kartlegging av resultater. Her møter arbeidstakers ansvarlighet, i denne sammenhengen definert som accountability eller regnskapsplikt, arbeidsgivers behov for kontroll. Dette får konsekvenser for arbeidsprosessene, som preges av rasjonalisering og mer spesialisering. Normering, målstyring og kontroll virker inn på muligheten for selvstendighet og utøvelse av faglig skjønn. Jensen og Walker beskriver dette som en fremmedgjøringsprosess som den enkelte profesjonsutøver utsettes for. Det skapes avstand mellom den ansatte og formålet med arbeidet. Moderniseringen er basert på mistillit til profesjonsfagenes kompetanse og selvstendighet, materialisert gjennom prinsippet om regnskapsplikt. Overvåkning og kontroll og avstand til politiske og administrative autoriteter manipulerer fram en konform

1 De presenterer en diskursiv analysemodell i fire lag fra makro- til mikronivå, og drøfter hvordan kombinasjonen av sørvisytelser i økende grad i den offentlige sektor, og konkurranseaspektet med sammenlikninger av prestasjoner og mer presise standarder, bidrar til nye diskurser. Disse diskursene, mener de, er helt avgjørende for hvordan pedagogisk ledelse kan utfolde seg, og for vilkårene for hvordan lærere og elever kan forme sine roller. (Jensen \& Walker, 2007). Slik jeg oppfatter det, bidrar denne modellen til å utfylle bildet Gitz-Johansen gir av autoritær modernitet. 
atferd. I tillegg kan dette bringe med seg mangel på kollegialt samarbeid som følge av konkurranse om belønnende prestasjoner. Vekselvirkningen mellom disse forholdene preger profesjonsutøveren. Standardisering og normering beskrives som nøkkelen som muliggjør denne dialektiske fremmedgjøringsprosessen. Den er tilsynelatende vitenskapelig og rasjonell, men skapes egentlig av «ideologiske manipulasjoner». Moderniseringen av offentlig sektor bidrar til å forenkle prosessene, og står i kontrast til den humanistiske og progressive tradisjonen. Der er det ikke et mål å bare reprodusere og overlevere kunnskap, men der har nyskaping og kreativitet verdi, og den pedagogiske praksis utfoldes i et fellesskap.

\section{Å FORENKLE DET KOMPLEKSE}

«Vi vil gjøre Norge enklere» er et av mantraene til statsminister Erna Solberg. Regjeringens plattform definerer målsettinger for barnehagen (Regjeringen, 2013, s. 54). Der står det blant annet at de vil innføre mer fleksible åpningstider tilpasset brukernes behov, og arbeide for økt fleksibilitet i barnehageopptaket. De ønsker å gjøre mest mulig informasjon åpent tilgjengelig og vil innføre felles nasjonale indikatorer for kvalitet.

Gitz-Johansen peker på en dreining i språket om barndom. For eksempel er det i dag mer snakk om barns kompetanser, til forskjell fra "det kompetente barn". Noen mener også at reformpedagogiske begreper som frihet, autonomi og valg nå bærer i seg verdier fra helt andre kontekster, og at et ensidig fokus på disse kan skape forventninger barn ikke er i stand til å innfri (Thoresen, 2009). Min antagelse er at de siste årenes økende bruk av markedsbegreper i barnehagesammenheng har bidratt til å skape et mulighetsrom for moderniseringsprosesser på barnehageområdet.

Vi kan se tendenser til slike moderniseringsprosesser med økende grad av felles målstyring og standardisering av barnehagene i mange kommuner. Kanskje har Oslo kommune kommet lengst med innføring av Oslo-standarden. Utviklingen skjer gradvis, så barnehagelæreren knapt merker det, når hverdagen består av relasjoner til atten barn, planlegging, turer og fordyping i lek. Man fyller ut de skjemaene man må, krysser av på gjort-listen, og plutselig står man kanskje i et nytt pedagogisk paradigme og lurer på hva som egentlig skjedde. Kanskje er det en bevisst og villet endring fra styrende organer. Kanskje er det uttrykk for en indirekte styring vi kan definere som governmentality. Språk endrer hvordan vi tenker og handler, og gir rom for ny politikk, og ny praksis. Her mener jeg å kunne trekke paralleller til Katrin Hjorts (2008) drøfting av ulike velferdsmodeller. Hun hevder at hvilket system vi til sist velger å bygge samfunnet på, beror på hvilket menneskesyn vi legger til grunn. Man kan altså ikke endre hvordan vi tenker om og styrer barnehageområdet $\mathrm{i}$ retning av NPM-tenkning, uten at dette også endrer hvilke grunnleggende verdier og menneskesyn man legger til grunn. Denne retningen bærer i seg et annet syn på barn og barndom enn det jeg mener å finne i barnehageloven om at barnehagen skal anerkjenne barndommens egenverdi. Det er her utfordringen ligger for den enkelte barnehagelærer, og for barnehagefaglige miljøer. Det er i dette mulighetsrommet anerkjennelsen av barndommens egenverdi kan stå på spill. Så hvordan møter vi utfordringene?

Solberg ønsker forenkling og nasjonale standarder. Visjonen om å utvikle Norge som kunnskapsnasjon forutsetter at barn bidrar til å oppfylle den, og grunnlaget skal legges allerede i barnehagen (Seland, 2010). Barn er kanskje den gruppen mennesker i samfunnet som i størst grad merker effektene av politikk uten å selv ha noe å si for utformingen av denne politikken. Dette legger et stort ansvar på barnehagelærere og styrere for å ivareta barns perspektiv. Samtidig er det helt nødvendig at forskningen bidrar til å synliggjøre 
kompleksiteten i de ulike faglige områdene som berører barnehagen. Seland påpeker at forskning brukes til å legitimere politiske valg, og oppfordrer til at stillheten om den forskningen som ikke bekrefter det rådende eller det ønskelige, må brytes. Dette er et perspektiv som også støttes av Jensen og Walker (2007).

I den humanistiske pedagogiske tradisjonen er det en kjensgjerning at pedagogiske spørsmål sjelden eller nesten aldri bare har ett tydelig svar. Kristin Halvorsens pragmatiske holdning til bruk av språk og nye diskurser om intensjonene med barnehagen, kan ha vært et av mange bidrag til en utilsiktet endring. Jo oftere meningsbærende aktører snakker om avkastning, forebygging og framtidig arbeidskraft istedenfor forhold som bidrar til å legitimere et fortsatt fokus på barndommens egenverdi, desto mer bidrar de til å endre befolkningens tenkning om barndom og barnehagens formål. OECD berømmer den norske barnehagen for å balansere omsorg, lek og læring på en helhetlig og hensiktsmessig måte. Samtidig kritiserer de Norge for den lave pedagogtettheten i barnehagene. Jeg tenker at det er verdt å lytte godt til OECD i denne sammenhengen (Thoresen 2009). Forenklingen som ser ut til å være en rådende politisk vilje - må møtes med kompleksitet, økonomiske prinsipper må møtes med faglige begrunnelser, og ensretting i pedagogisk grunnlagstenkning må møtes med krav om metodefrihet. Dette er nødvendig for å bidra til å bevare barnehagens anerkjennelse av barndommens egenverdi.

\section{LITTERATUR}

Gitz-Johansen, T. (2009). Barndommens modernisering: om den autoritære modernitets genkomst. I S. Højlund (Red.), Barndommens organisering: $i$ et dansk institusjonsperspektiv (s. 57-88). Roskilde Universitetsforlag.

Hjort, K. (2008). Farvælferdsstat - skal vi selge velferden for at beholde den? I K. Jensen \& N. R. Jensen (Red.), Global uddannelse lokalt demokrati: peedagogisk sociologi III (1. utg., s. 129-151): Danmarks pædagogiske universitetsforlag.

Jensen, K., \& Walker, S.A. (2007). Diskurser om modernisering af den offentlige sektor. I K. Jensen \& N. R. Jensen (Red.), Modernisering af den offentlige sektor (s. 123-141). Aarhus: Danmarks Pædagogiske Universitetsforlag. Johansson, J.-E. (2010). Från pedagogik till ekonomi? Några kommentarer till kunskapsproduktionen i barnehagen. Tidsskrift for Nordisk Barnehageforskning, 3(3), 227-231.
Kampmann, J. (2009). Barndommens rationalisering og rationering: om børns pædagogiske hverdagsliv. I S. Højlund (Red.), Barndommens organisering: $i$ et dansk institutionsperspektiv (1. utg., s. 149-172). Roskilde universitet: Roskilde universitetsforlag.

Kunnskapsdepartementet. (2011). Rammeplan for barnehagens innhold og oppgaver. Oslo.

Kunnskapsdepartementet. (2013). Framtidens barnehage Meld. St. 24 (2012-2013).

Regjeringen. (2013). Politisk plattform: for en regjering utgått av Høyre og Fremskrittspartiet. Sundvollen. Hentet fra http://www.hoyre. no/filestore/Filer/Politikkdokumenter/ plattform.pdf

Seland, M. (2010). Barndomsforskning i dag: med særlig vekt på "Politics of childhood". Barn, 28(2), 65-79.

Thoresen, I. T. (2009). Barnehagen i et utdanningspolitisk kraftfelt. Nordisk barnehageforskning, 2(3), 127-137. 